\title{
Kaksivaihekasvatuksen kannattavuus lammastaloudessa Tuotannon perusteet sekä kannattavuuslaskurin kehittäminen
}

\author{
Kauppinen Juho-Heikki ${ }^{2}$, Viitala, Hannu ${ }^{1}$, Korhonen Arja ${ }^{1}$, Suhonen Pirjo ${ }^{1}$, Heltelä Sari ${ }^{3}$ \\ ${ }^{1}$ Savonia-ammattikorkeakoulu, PL 72, 74101 Iisalmi, etunimi.sukunimi@savonia.fi \\ ${ }^{2}$ ProAgria Pohjois-Savo, etunimi.sukunimi@proagria.fi \\ ${ }^{3}$ ProAgria Etelä-Savo, etunimi.sukunimi@proagria.fi
}

Lammastalous on ainoita kasvavia tuotantosuuntia tällä hetkellä suomalaisessa maataloudessa. Asiaan ovat vaikuttaneet erityisesti alan ammattimaistuminen, muun tuotantosuunnan lopettavien yrittäjien siirtyminen lammastalouteen sekä kulutuksen voimakas kasvu. Lampaanlihan kulutus on kuitenkin ollut Suomessa vuosikymmeniä suurempi kuin sen tuotanto ja lammastilojen kannattavuus on ollut pitkään heikohko. Uusien ja tehokkaiden tuotantomuotojen harkitseminen sekä kehittäminen on välttämätöntä. Yhtenä vaihtoehtona on kaksivaihekasvatus. Se on tuotantomuoto, jossa uuhitila myy karitsat vieroituksen jälkeen loppukasvatukseen. Näin uuhitilalla vapautuu lampolassa lisää pinta-alaa uuhien käyttöön, säästetään työaikaa sekä voidaan erikoistua uuhien hoitoon. Tähän asti ongelma on ollut löytää uuhitiloja, jotka möisivät karitsoita. Sen sijaan loppukasvatustoimintaa harkitsevia lampureita on ollut useita. Tässä kehittämistyössä on tuotoksena kaksivaihekasvatuksen kannattavuuslaskuri ja raportissa on kuvattu suunnitteluprosessi. Raportti toimii laskurin käytön tukena sekä täydentää laskuria muun muassa avaamalla siinä käytettyjä termejä. Työssä pureudutaan kaksivaihekasvatukseen siirtymisen tuomista muutoksista uuhitilan talouden kannalta. Tilakohtaiset laskelmat voidaan laskea toteutetulla kannattavuuslaskurilla, jossa on nykytilanteen lisäksi kuusi erilaista vaihtoehtoa kaksivaihekasvatukselle. Laskurissa selvitetään tilan nykyhetken tuotot sekä muuttuvat kustannukset, minkä jälkeen lopputuloksena saadaan kate kiinteille kustannuksille (Enroth ja Pellinen 2008). Vaihtoehdoissa rajoittavia tekijöitä ovat ruokinta sekä vapautuva tila. Onko kaksivaihekasvatus kannattavampi vaihtoehto kuin perinteinen yhdistelmätuotanto? Kannattavuuteen vaikuttavat tekijät ovat tilakohtaisia. Laskurilla selvitetään, onko kaksivaihekasvatus kannattava vaihtoehto tilalle. Yleisesti kaksivaihekasvatuksen kannattavuuteen uuhitilalla vaikuttavat päiväkasvu, karitsoiden myyntihinta sekä uuhiin käytetty työmäärä. Testauksen perusteella kaksivaihekasvatus soveltuu heikoiten suoramyyntitiloille. Parhaiten se soveltuu suomenlampaille niiden ympärivuotisen tiinehtyvyyden sekä alkuperäisrotustatuksen ansiosta. Kaksivaihekasvatuksella pystytään tehostamaan tilan tuotantoa ja parantamaan kannattavuutta, kaksivaihekasvatus ei ole ratkaisu, jos tilan perustuotannossa on ongelmia. Lammastaloudesta on tehty Suomessa vähän tutkimusta verrattuna esimerkiksi lypsykarjatalouteen, joten lisätieto olisi erittäin tarpeellista nykyisessä nousukaudessa. Mielenkiintoisia tutkittavia aiheita olisivat esimerkiksi tuotantorenkaan mallintaminen kaksivaihekasvatukseen, työajan tutkimus ja työtehokkuuden lisääminen sekä teurastamoiden näkökulma kaksivaihekasvatuksen yleistymisestä ja sen myötä tasaisemmasta lampaanlihan tarjonnasta. Kaksivaihelaskuri on tehty osana Katras-koulutushanketta ProAgrian lammasasiantuntijoiden käyttöön. Laskurista tulee myöhemmin kevyempi testiversio yrittäjien käyttöön.

Avainsanat: lammastalous, kaksivaihekasvatus, uuhitila, kannattavuus, kannattavuuslaskuri, katetuotto 


\section{Johdanto}

Lammastalous on tällä hetkellä yksi harvoista kasvavista suomalaisen maatalouden tuotantomuodoista, ja entistä useampi muun tuotantosuunnan lopettava yrittäjä harkitsee siirtymistä lammastalouteen. Lampurit ovat innokkaita kehittämään omaa toimintaansa ja ovat aktiivisia tiedon kerääjiä sekä jakajia. Sen todistaa muun muassa koulutuksien ja hankkeiden suuri osallistujamäärä sekä aktiviinen sosiaalisenmedian verkostojen hyödyntäminen. Alan suosion ja lampaista saatavien tuotteiden kysynnän kasvaessa tulee myös tuotannon kehittyä.

Suomen omavaraisuusastetta lampaanlihan osalta voidaan pitää heikkona, minkä takia lammastaloutta tulisi kehittää tehokkaammaksi ja kannattavammaksi. Yksi näistä keinoista voi olla kaksivaihekasvatus, jolla saadaan lihantuotantoon sekä lammastilojen yleiseen toimintaan lisää tehokkuutta. Kaksivaihekasvatuksessa uuhitila myy karitsat vieroituksen jälkeen loppukasvattamoon, joka kasvattaa karitsat teuraaksi asti. Myynnin seurauksena uuhitilalla muun muassa vapautuu tilaa lisäuuhille, ruokintakustannukset pienenevät sekä työmäärä vähenee. (Kauppinen 2011.) Kyseinen tuotantomuoto on kuitenkin Suomessa vielä varsin harvinainen, sillä lähes kaikki lammastilat kasvattavat karitsat itse teuraiksi asti. Maailmanlaajuisestikaan kaksivaihekasvatus ei ole kovin yleistä, johtuen lähinnä suurimpien lampaanlihantuottajamaiden laidunruokintaan perustuvasta kasvatuksesta. Jonkin verran sitä kuitenkin harjoitetaan esimerkiksi Ruotsissa ja Isossa-Britanniassa.

Kokemusta kaksivaihekasvatuksesta on hyvin harvalla lammastilalla. Tällaisia tiloja on arviolta noin kymmenkunta, mutta kiinnostus tuotantomuotoa kohtaan kasvaa koko ajan. Kiinnostusta on erityisesti loppukasvattamotoimintaan, mutta uuhitilojen mukaan saaminen on ollut tähän asti haaste. Tämä käy ilmi Tosilampuri-hankkeen loppuraportista, joka on saatavilla osoitteesta https://www.proagria.fi/sites/default/files/attachment/4273_tosilampuri_loppuraportti_30.1.2015_ww w.pdf. Kaksivaihekasvatusta on tutkittu melko vähän, joten lisätiedolle on todella tarvetta.

Työn hypoteesina oli "kaksivaihekasvatus on kannattavampaa kuin perinteinen yhdistelmätuotanto". Tavoitteena oli perustella asiaa erityisesti uuhitilojen yrittäjille, joiden innostus kaksivaihekasvatukseen on ollut vielä varsin heikkoa. Työn tavoitteena on saada aikaan muutosta suomalaisessa lampaanlihan tuotannossa siten, että se on sekä tehokkaampaa että kannattavampaa. Tehokkaammalla tuotannolla pystyttäisiin vastaamaan paremmin lampaanlihan kysyntään kotimaassa sekä mahdollisesti tulevaisuudessa ulkomaan vientiinkin. Tehokkaammalla tuotannolla tuotannon kapasiteetti saadaan hyödynnettyä paremmin, mikä lisää yleensä myös kannattavuutta. Harvalla lammastilalla on ajateltu tarkemmin erityisesti tuotannosta koituvia kustannuksia, mutta tuotot ovat sen sijaan hyvin tiedossa. Kehittämistyönä tehdyn laskurin avulla pystytään herättelemään lampureita myös kustannusten tarkempaan seuraamiseen.

Tutkimus on ollut osa ProAgrian Katras-koulutushanketta, jonka tavoitteena on tehostaa suomalaista lammastaloutta, kehittää lammastilojen johtamista sekä parantaa niiden kannattavuutta. Hankkeessa ovat mukana ProAgriat Pohjois-Savo, Pohjois-Karjala sekä Kainuu.

\section{Materiaalit ja menetelmät}

Tutkimus on toiminnallinen, siihen kuuluu tässä työssä laskurin kehittäminen ja kehitysprosessia kuvaava raportti. Toiminnallisen tutkimuksen tavoitteina on käytännön toiminnan ohjeistaminen, toiminnan järkeistäminen sekä sen järjestäminen ammatillisessa toimintaympäristössä. Laadullisen tutkimuksen periaatteiden mukaisesti tärkeää on kohdejoukon valinta (Hirsijärvi ym. 1997). Tässä tutkimuksessa kohdejoukkona ovat lammastalousyrittäjät, joilla on kokemusta kaksivaihekasvatuksesta. Mukana oli myös perinteisiä tiloja, joilta saatua tietoa on verrattu ja sovellettu kaksivaihekasvatuksesta kokemusta omaavien tilojen tietoihin. Haastattelut olivat teemahaastatteluja, joissa aihe oli selvä, mutta tarkat kysymykset puuttuivat osittain (Hirsijärvi ym. 1997). Haastattelut tehtiin tilavierailuiden yhteydessä, jolloin tehtiin samalla havainnointia. 
Kaksivaihekasvatuksen kannattavuuslaskurin suunnitteluvaiheessa määriteltiin, mitä laskurilla pitää pystyä laskemaan ja mitkä asiat jätetään laskurin ulkopuolelle. Alustavasti suunniteltiin myös, miten laskuria testataan. Ulkopuolelle jääneet asiat perustellaan raportissa. Näin osoitetaan se, että vaikutus on tiedostettu, mutta merkitys laskurin kannalta ei ole oleellinen (Hiltunen 2016).

Ensimmäiset versiot laskurista olivat hyvin yksinkertaisia ja pelkistettyjä. Nykytilanteen lisäksi oli vain yksi vaihtoehtotilanne kaksivaihekasvatukselle, jossa huomioitiin muutokset tilan tarpeessa, eläintuissa sekä lihanmyynnin tuotoissa. Tässä vaiheessa ei keskitytty ulkonäköön, mutta käytettävyyttä ajateltiin koko laskurin tekoprosessin ajan. Laskurin ollessa toimivuudeltaan hyvä alettiin ulkomuotoon kiinnittää huomiota. Myös loput viisi vaihtoehtoa kaksivaihekasvatukselle luotiin tässä vaiheessa, sillä ensimmäisen vaihtoehdon pohja oli toimiva. Vaihtoehtoja lisättiin, sillä eri tiloilla on erilaisia tuotantotapoja. Vaihtoehtojen lisäyksellä saa myös parempaa vertailumateriaalia, kun laskuri laskee valmiiksi eri vaihtoehtojen katetuoton. Lopuksi la tehtiin lisäksi oma versio luomutiloille, missä huomioidaan muun muassa erilaiset hintatiedot sekä tuet. Laskuri on tehty Microsoft Excel-pohjaan (Taulukko 1).

\begin{tabular}{|c|c|c|c|c|c|c|}
\hline Uuhen & \multicolumn{3}{|c|}{ katetuottolaskelma } & & & \\
\hline \multirow[t]{2}{*}{ Tuotto } & \multicolumn{3}{|c|}{ Yhdistelmätuotano } & \multicolumn{3}{|c|}{ Kaksivaihekasvatus } \\
\hline & Määrä & á & $€$ & Määrä & á & $€$ \\
\hline Liha (karitsa $18 \mathrm{~kg}$ ).... & 36 & 3,79 & 136 & 40 & 3,79 & 152 \\
\hline Liha (poistouuhi $30 \mathrm{~kg}$ ) & 6 & 0,88 & 5 & 6 & 0,88 & 5 \\
\hline Villa & 2 & 1,00 & 2 & 2 & 1,00 & 2 \\
\hline Talja & 0,20 & 80,00 & 16 & 0,20 & 80,00 & 16 \\
\hline Tuet & 1 & 142,04 & 142 & 1 & 142,04 & 142 \\
\hline Tuotto yhteensä & & & 302 & & & 317 \\
\hline \multicolumn{7}{|l|}{ Muuttuyat kustannukset: } \\
\hline Säilörehu & 180 & 0,124 & 22 & 195 & 0,124 & 24 \\
\hline Heinä & 150 & 0,137 & 21 & 160 & 0,137 & 22 \\
\hline Rehuvilia & 160 & 0,156 & 25 & 180 & 0,156 & 28 \\
\hline Zaidun & 250 & 0,101 & 25 & 250 & 0,101 & 25 \\
\hline Kivennäiset & 5 & 0,780 & 4 & 5 & 0,780 & 4 \\
\hline Rypsitiiviste. & 10 & 0,385 & 4 & 17 & 0,385 & 7 \\
\hline \multirow{4}{*}{ Muut musttuvat kust. } & 1 & 25.00 & 25 & 1 & 25.00 & 25 \\
\hline & & & 0 & & & 0 \\
\hline & & & 0 & & & 0 \\
\hline & & & 0 & & & 0 \\
\hline Eläinpääoman korko & 0,05 & 150,00 & 8 & 0,05 & 150,00 & 8 \\
\hline liikepääoma $60 \%$ & 0,60 & & & 0,60 & & \\
\hline Liikepääoman korko $5 \%$ & 0,05 & 75,50 & 4 & 0,05 & 80,93 & 4 \\
\hline Muuttuvat kustannukset yht & & & 137 & & & 146 \\
\hline Katetuotto A & & & 165 & & & 170 \\
\hline Ihmistyö & 7,2 & 16,2 & 117 & 7,2 & 16,2 & 117 \\
\hline Katetuotto B & & & 48 & & & 54 \\
\hline
\end{tabular}

Taulukko 1. Esimerkki katetuottolaskelmasta uuhelle (Juho-Heikki Kauppinen 2016).

Laskuria testasivat neljä Savonia ammattikorkeakoulun agrologiopiskelijaa. Laskuri testattiin viidellä todellisella lammastilalla, lisäksi laskurin toimivuutta ja laskelmien realistisuutta kommentoivat ProAgrian lammasneuvojat. Lopullinen versio laskurista on ProAgrian lammasneuvojien käytössä.

Kannattavuuslaskurissa lasketaan kate kiinteille kustannuksille. Laskenta perustuu nykytilanteeseen syötettyihin tietoihin, minkä perusteella laskuri laskee vaihtoehtoiset katetuotot kuudelle eri vaihtoehdolle:

1. Suurin mahdollinen uuhimäärä samalla ruokinnalla kuin nykytilassa. 
2. Suurin mahdollinen uuhimäärä samalla ruokinnalla kuin nykytilassa ja tiheä karitsointi.

3. Suurin mahdollinen uuhimäärä vapautuvaan tilaan perustuen

4. Suurin mahdollinen uuhimäärä vapautuvaan tilaan perustuen ja tiheä karitsointi.

5. Hyvinvointikorvaustilan suurin mahdollinen uuhimäärä vapautuvaan tilaan perustuen.

6. Hyvinvointikorvaustilan suurin mahdollinen uuhimäärä vapautuvaan tilaan perustuen ja tiheä karitsointi.

Laskurissa hyödynnettäviä muuttuvia kustannuksia ovat ruokinta-, työ-, uudistus- ja kuivituskustannukset. Lisäksi on mahdollista eritellä muita yleisiä kustannuksia, kuten keritsemis-, aitaus ja eläinlääkintäkustannuksia. Tuottojen osalta huomioidaan lihanmyynti, jalostuseläinten myynti sekä kotieläintuet. Vaihtoehdoissa lasketaan vaikutus siihen, jos lihakaritsat myytäisiinkin loppukasvatukseen vieroituksen jälkeen.

\section{Tulokset ja tulosten tarkastelu}

Yleistä vastausta siihen ei voi antaa, onko kaksivaihekasvatus tehokkaampi tuotantomuoto kuin perinteinen yhdistelmätuotanto. Laskurin avulla voidaan kuitenkin selvittää tilakohtaisesti, sopiiko kaksivaihekasvatus kyseiselle tilalle. Tulokset riippuvat muun muassa lihan myyntihinnasta ja myyntitavasta, työajan käytöstä sekä saaduista tuista. Näin ollen tulokseksi voidaan saada toisen tilan osalta, että kaksivaihekasvatukseen siirtyminen on hyvinkin kannattava vaihtoehto, kun taas toiselle tilalla se ei sovi ollenkaan. Kaksivaihekasvatus ei ole järkevä vaihtoehto suoramyyntitiloille, sillä lihan hinta on tällöin huomattavasti korkeampi. Toisaalta asiaan vaikuttaa se, kuinka paljon suoramyyntiin kuluu resursseja. Muita selkeästi esille nousseita asioita olivat hyvinvointikorvauksen positiivinen vaikutus tilan talouteen, tiheän karitsoinnin heikentävä vaikutus talouteen sekä alkuperäisrotutuen positiivinen vaikutus tilan talouteen.

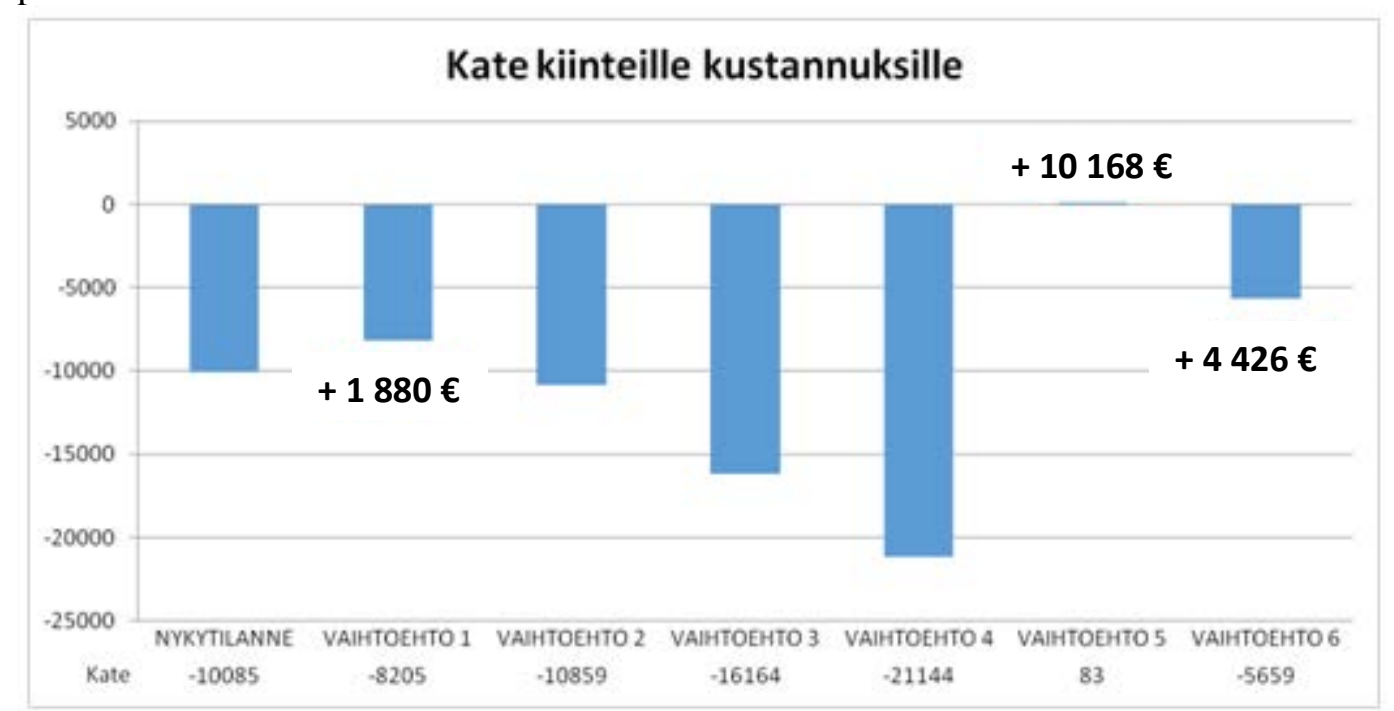

Kuva 1. Päiväkasvuksi on määritelty 200 g päivä-1

Kuvissa 1 ja 2 on käytetty esimerkkeinä päiväkasvun ja karitsoiden myyntihinnan vaikutusta katetuottoon. Punaisella merkityt luvut ilmaisevat sen, kuinka paljon parempi vaihtoehdon kate on verrattuna nykytilanteeseen. 


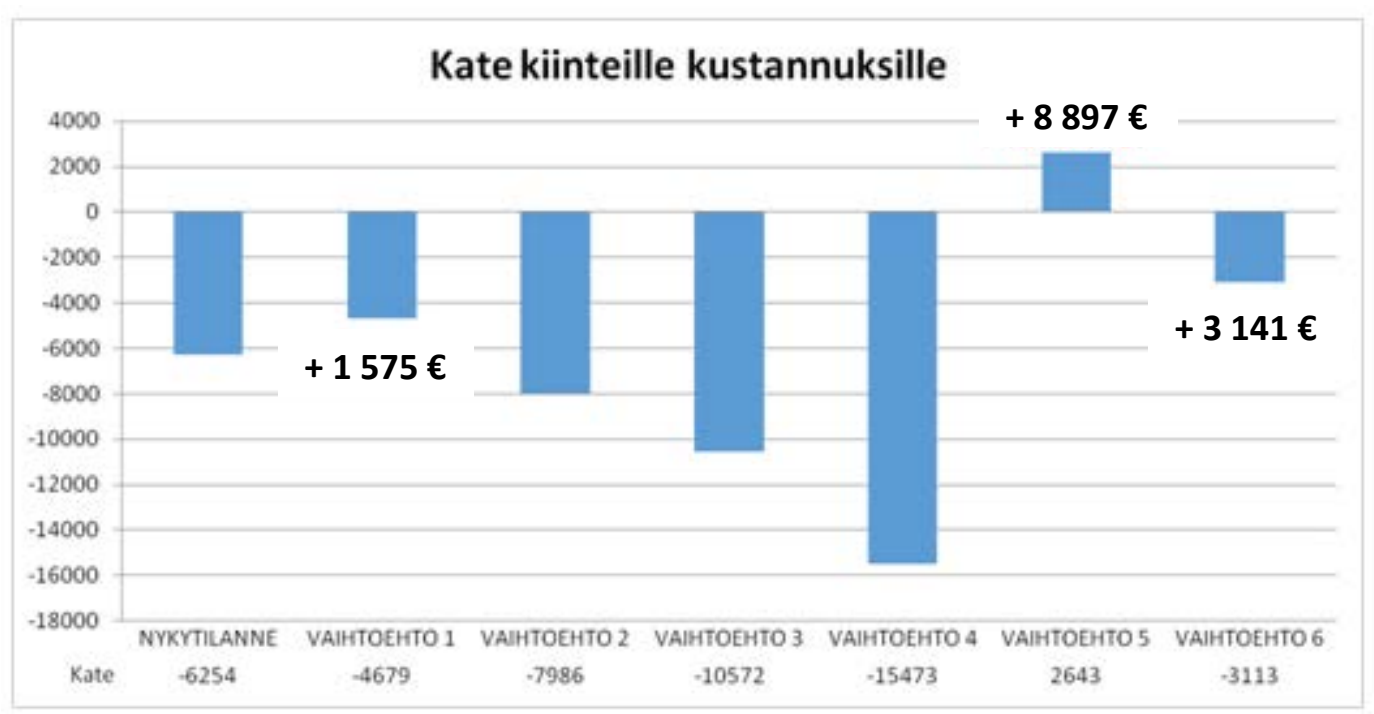

Kuva 2. Päiväkasvuksi on määritelty 400 g päivä-1 $^{-1}$

Päiväkasvulla on suuri vaikutus tilan talouteen riippumatta siitä, onko kyseessä normaalituotantotapa vai kaksivaihekasvatus. On kuitenkin pääteltävissä, että mitä parempi päiväkasvu karitsoilla on, sitä parempi tulos myös kaksivaihekasvatukseen siirtymisellä saavutetaan. Voidaan kuitenkin myös ajatella, että jos lähtötilan karitsoilla on heikot päiväkasvut, on sen suhteellisesti kannattavampaa myydä karitsat kasvatettavaksi kuin kasvattaa itse. Tällöin se säästää ruokintakustannuksissa ja hyöty on suurempi. Loppukasvatustilan kannalta on kuitenkin parempi, että päiväkasvut olisivat hyvällä tasolla, jotta tuotannon tasaisuus säilyisi eivätkä kasvatusajat venyisi.

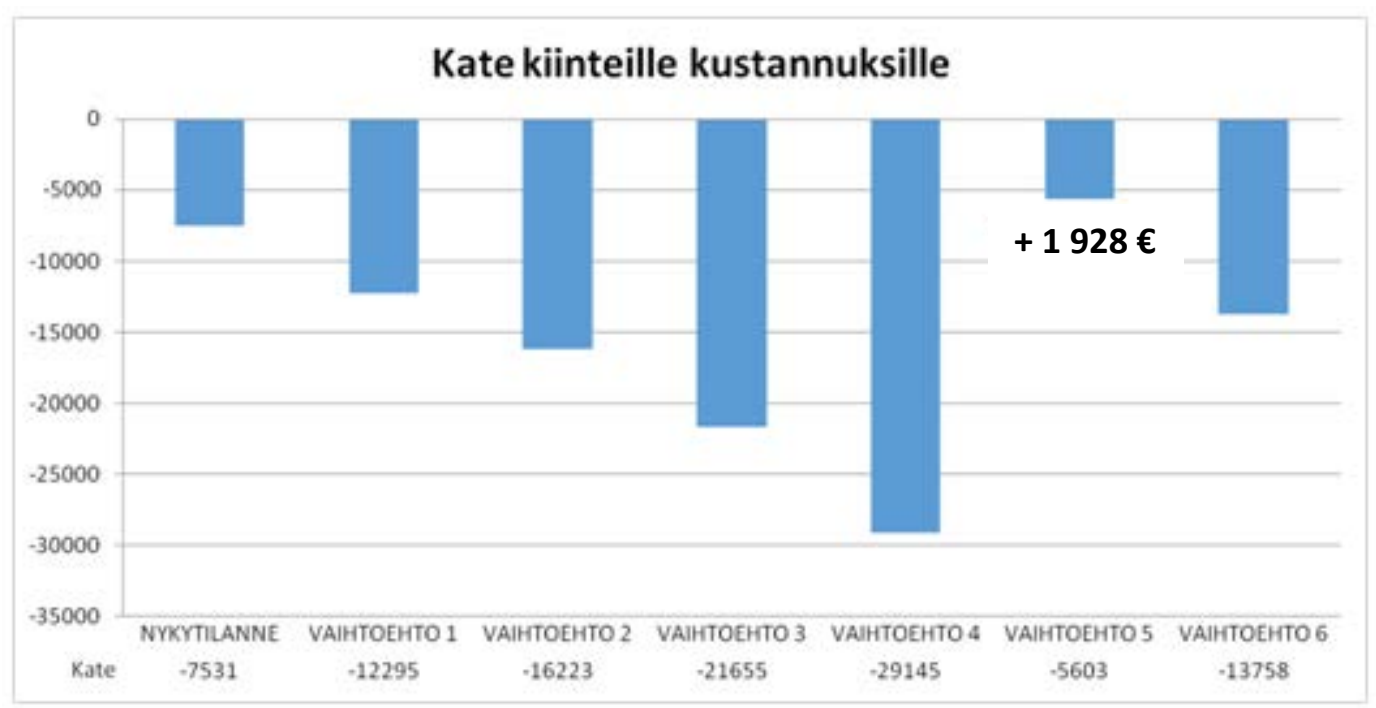

Kuva 3. Karitsan myyntihintana on käytetty 2 €/elopaino kg

Karitsan myyntihinta on yksi keskeisimmistä tekijöistä, mikä vaikuttaa kaksivaihekasvatuksen kannattavuuteen. Tulosten perusteella myyntihinnan on oltava vähintään noin $2,5 € \mathrm{~kg}^{-1}$, jotta kaksivaihekasvatuksella on oikeasti kannattavuutta kehittävä vaikutus. Vaikka joissakin tapauksissa alempikin hinta riittää parantamaan kannattavuutta, vaikuttaa tuotannon kokonaisuus lopputulokseen. Myyntihinta on kuitenkin järkevää asettaa kiinteäksi €/elopaino kg, sillä tämä kannustaa uuhitilaa kasvattamaan karitsat alusta asti tehokkaasti, mitä loppukasvattaja voi sitten jatkaa omalla tilallaan. Kiinteä elopainoon perustuva hinta myös asettaa eri uuhitilat tasa-arvoisempaan asemaan myyntihetkellä, sillä näin tehokkaasti karitsoita tuottava ja kasvattava tila saa työlleen ansaitsemansa korvauksen (Kuva 3). 


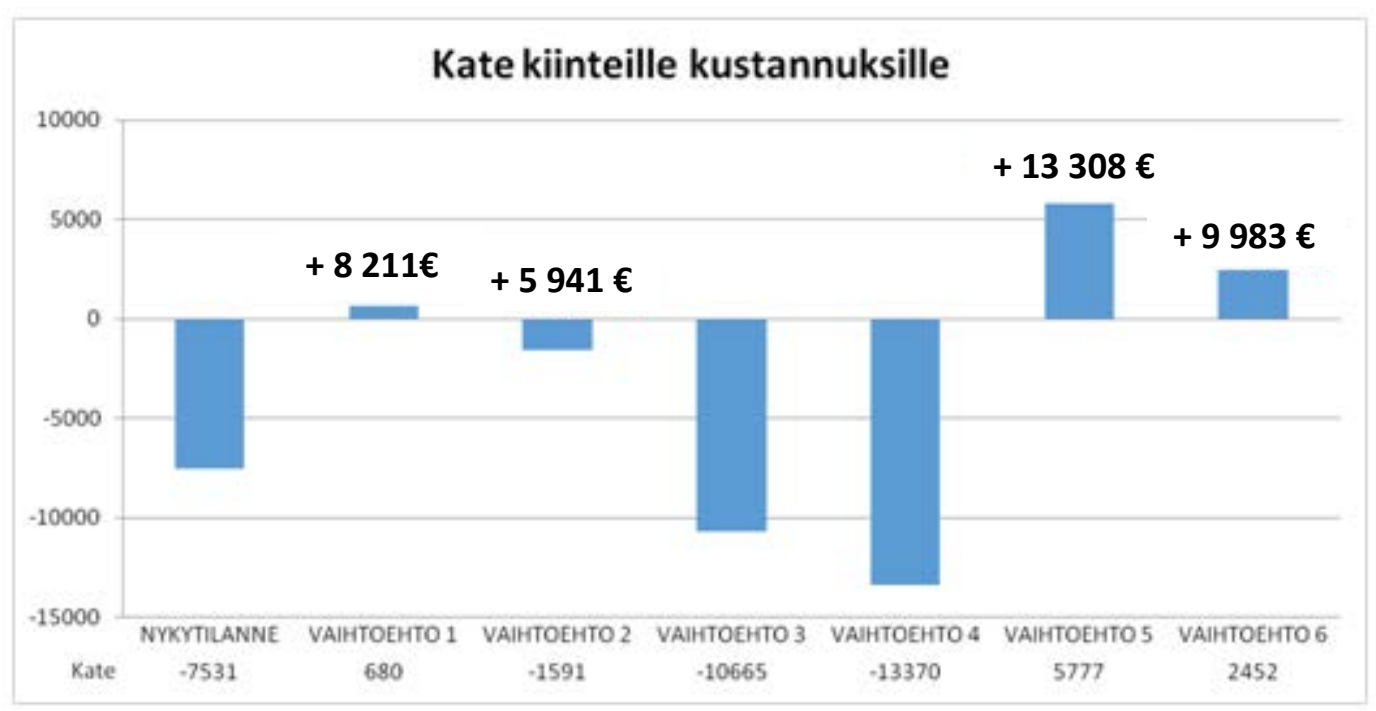

Kuva 4. Karitsan myyntihintana on käytetty 3€/elopaino kg.

Pelkkä myyntihinta ei ole kuitenkaan ratkaiseva tekijä kaksivaihekasvatuksen kannattavuudessa, vaan siihen vaikuttavia tekijöitä on useita ja ne ovat tilakohtaisia. Työssä ei oteta kantaa sopivaan hintaan ostajan kannalta, joten tarkkaa sekä ostajalle että myyjälle tasapuolista myyntihintaa ei pystytä sanomaan. ProAgrian karitsanlihan kannattavuuslaskurilla pystytään haarukoiman tätä hintaa loppukasvattamon kannalta laskettaessa lihakaritsan tuotantokustannusta.

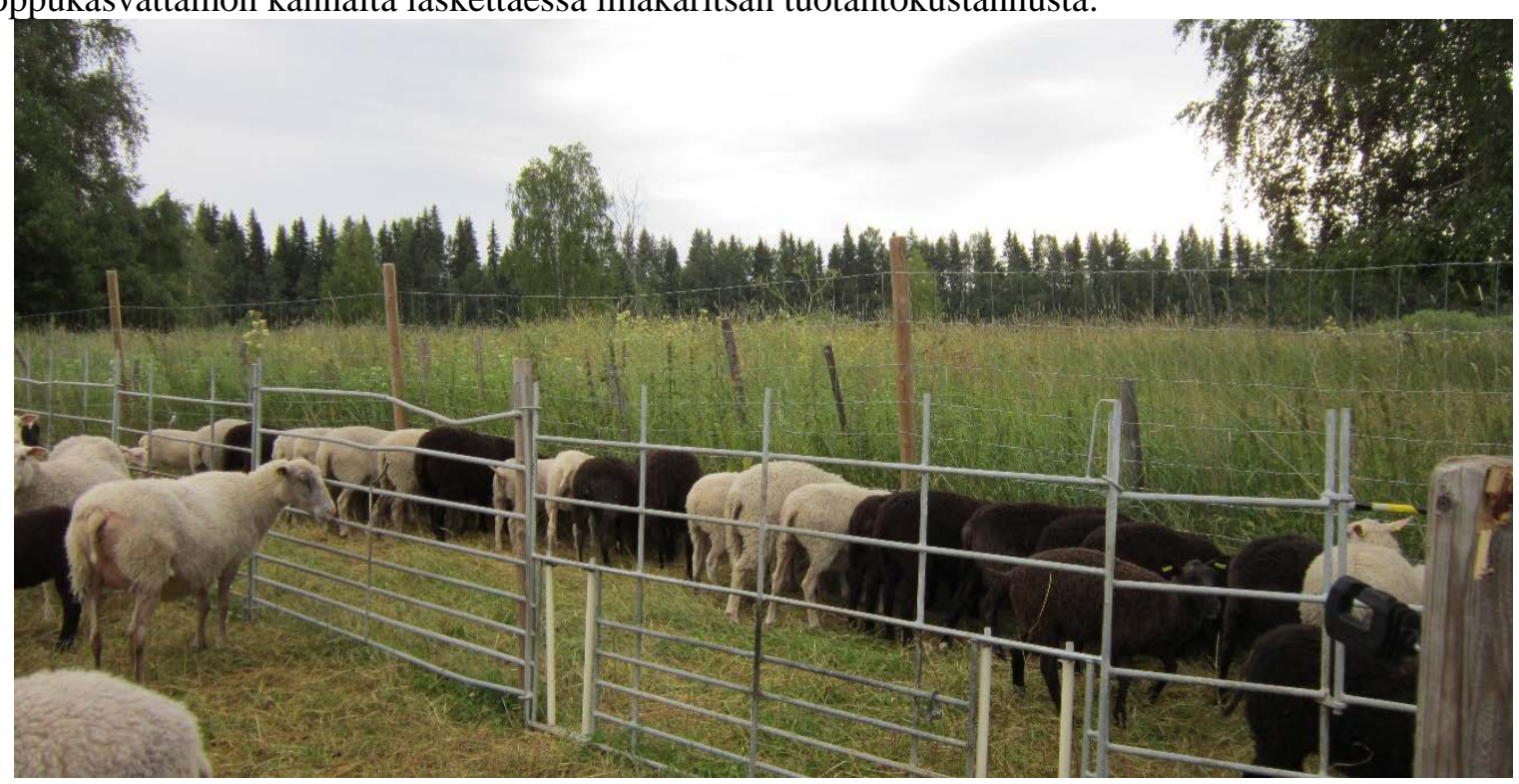

Kuva 5. Karitsabaarilla turvataan karitsoiden ruokintaa. Kuvassa baari on perustettu laitumelle (Juho-Heikki Kauppinen 2013).

\section{Johtopäätökset}

Testitulosten perusteella kaksivaihekasvatus voi olla kannattava vaihtoehto tehokkaassa lammastaloudessa. On kuitenkin muistettava, että laskurin antamat tulokset ovat suuntaa antavia, eivätkä ne vastaa täysin käytännössä saatavia lukemia. Tämä johtuu muun muassa siitä, että syötetyt tiedot ovat sen hetkisen tilanteen mukaisia ja esimerkiksi eläinmäärissä, tuottajahinnoissa sekä satotasoissa tapahtuu vuosittain muutoksia. Lisäksi tulosten tarkkuuteen vaikuttaa se, kuinka hyvin yrittäjät osaavat arvioida esimerkiksi lampaitten hoitoon kuluvan työajan ja jakaa sen uuhien sekä karitsoiden kesken. 
Tuloksista on huomattavissa, ettei tiheä karitsointi olisi kannattava vaihtoehto tuloksen parantamiseksi. Tämä johtuu osaltaan siitä, että laskurissa työmäärä ja työkustannus on kerrottu 1.3:lla tiheän karitsoinnin vaihtoehdoissa. Luku vastaa karitsointien määrä vuoden aikana tiheässä karitsoinnissa. Laskentatapa on kovin teoreettinen, minkä vuoksi tiheän karitsoinnin osalta tulos ei ole täysin paikkaansa pitävä. Todellista vaikutusta esimerkiksi työaikaan ei ole tutkittu ja voikin olla, että erikoistuessa pelkästään uuhiin, työaika ja -kustannus eivät olekaan 1.3-kertaisia. Lisäksi kaksivaihekasvatukseen siirtymisen seurauksena mahdollisesti tiiviimpi karitsointiaika säästää työaikaa ja sitä kautta myös kustannuksia, kun karitsointien seuraamiseen ei kulu niin paljon aikaa (Äärilä ja Harmoinen 2007).

Tuotannon kannalta järkevin vaihtoehto kaksivaihekasvatukseen on tuotantorengas, jossa yksi tila kasvattaa karitsat teuraaksi ja sen kanssa yhteistyössä toimii useampi uuhitila. Nämä uuhitilat tuottavat karitsoita loppukasvatustilalle. Tästä mallista on useita etuja sekä uuhitilalle että loppukasvatustilalle, joista yksi merkittävimmistä on toiminnan jatkuvuus sekä sen myötä loppukasvattamon tehokas täyttöaste. Myös tautiriskit pienenevät suljetussa tuotantorenkaassa. Täyttöasteella on suuri merkitys loppukasvattamon kannattavuuteen. Tuotantorenkaan ansiosta tilat voisivat myös tehdä yhteistyötä niin kotieläintenhoidossa kuin peltoviljelyssäkin. Yhteistyö toimii parhaiten, kun tilojen väliset etäisyydet eivät ole kohtuuttoman suuret. Esimerkiksi karitsointiaikana tilan työmäärä usein moninkertaistuu hetkellisesti, jolloin myös lisätyövoimalle on tarvetta. Yrittäjät olivat kokeneet laskurin hyödylliseksi ja mielenkiintoiseksi. Laskurin sanottiin helpottavan talouden seurantaa ja auttavana toiminnan kehittämisen ajatustyöskentelyä. Muutamilla tiloilla todettiin, ettei taloutta ole ajateltu aiemmin näin tarkasti ja tämän seurauksen sen seuraamiseen aiotaan kiinnittää enemmän huomiota jatkossa. Erityisesti työkustannukset herättivät ajatuksia ja jopa yllätti yrittäjiä. Testitulosten perusteella kaksivaihekasvatus voi kuitenkin olla kannattava vaihtoehto tehokkaassa lammastaloudessa ja vaikuttaa siltä, että mitä heikommin tilalla ja yleisesti tuottajahintojen osalta menee, sitä kannattavampaa on kaksivaihekasvatus uuhitilalle.

\section{Kirjallisuusviitteet}

Enroth, A. \& Pellinen, J. 2008. Kannattava maatilayritys. Taina Harmoinen (toim.). Keuruu: ProAgria Maaseutukeskusten Liitto. s. 15

Hiltunen, M. 2016. Johdatus tietojärjestelmiin: Kehittämistyön vaiheet ja elinkaarimallit. Oulun seudun ammattioppilaitos.

http://www.okol.org/verkkokurssit/datanomi/tietojarjestelmien_kaytto_ja_kehittaminen/johdatus_tietojarjestelmi in/johdatus_tietojarjestelmiin.html. (Viitattu: 30.3.2016.).

Hirsjärvi, S., Remes, P. \& Sajavaara, P. 1997. Tutki ja kirjoita. Porvoo: Tammi. 464 s.

Kauppinen, R. 2011. Hiehonkasvatuksen ulkoistaminen, opas kasvattajalle ja ulkoistajalle. Iisalmi: Savonia ammattikorkeakoulu. $9 \mathrm{~s}$.

Äärilä, M. \& Harmoinen, T. 2007. Lampaankasvattajan käsikirja. Porvoo: WS BookWell Oy. 10 s. 